\title{
PROMOTION OF CASSAVA CHIPS "TETTE" THROUGH INSTAGRAM AND FACEBOOK ACCOUNTS AT BUMDES MADULANG, OMBEN DISTRICT, SAMPANG REGENCY
}

\author{
Fedianty AUGUSTINAH ${ }^{1}$, Vieta Imelda $\mathrm{C}^{2}$, Yoosita AULIA ${ }^{3}$ \\ Administrasi Bisnis, Fakutas IImu Administrasi, Universitas Dr. Soetomo \\ Email: fedianty.augustinah@unitomo.ac.id
}

\begin{abstract}
Partners in the Community Partnership Program are Madulang Village-Owned Enterprises (Bumdes) in Omben District, Sampang Regency, which is managed by the Head of Madulang Village who has managed the production of Cassava Chips known as Tette. Madum Bumdes Kripik Cassava TETTE so far only uses one of the social media namely Whattshap (WA) alone as a means of promotion to sell its products but Madum Bumdes still has not utilized the various applications that have been provided by social media either through Android Mobile or wifi facilities that are currently rife at regions / villages at this time so that it can be said that the use of promotional facilities has not been maximized using Social Media such as Instagram and Facebook which has a wider range of promotions to increase the sales volume of TETTE chips. Some things that are considered a priority issue by Bumdes Madulang partners are problems creating accounts through social media Instagram and Facebook and marketing TETTE cassava chips through social media Instagram and Facebook. The solution provided is in the form of training (coaching and mentoring) carried out with the first chronological or phased strategy that is giving knowledge / opening insights to Madulang Village Business Entrepreneurs about the importance of using Facebook and Instagram social media as a means of promoting TETTE cassava chips and the second provide training on making Facebook and Instagram accounts as a means of promoting TETTE cassava chips. The third solution activity was to produce photos and promotional videos of TETTE sigkong chips. to fill Facebook and Instagram accounts and the fourth agreed solution is to evaluate the promotion of TETTE sigkong chips that have been carried out by Madulang Village-Owned Enterprises through social media accounts Facebook and Instagram.

Suggestions that can be used by several related parties to assist in the development of the business of tette chips in Bumdes Madulang, District of Omben, Sampang Regency, training for the use of social media as a means of promotion at present where training related to marketing and marketing communication through social media is urgently needed. local governments should be able to become facilitators for that.
\end{abstract}

Keywords: Promotion, Bumdes, Trip Chips, Facebook, Instagram 


\section{PENDAHULUAN}

\section{Analisis Situasi}

Kabupaten Sampang merupakan salah satu kabupaten yang terletak di Pulau Madura. Di sebelah timur berbatasan dengan Kabupaten Pamekasan. Di sebelah selatan berbatasan dengan Selat Madura. Sedangkan di sebelah barat berbatasan dengan Kabupaten Bangkalan. Luas wilayah Kabupaten Sampang yang mencapai 1233,33 km2 habis dibagi menjadi 14 kecamatan dan 186 desa / Kelurahan. Lokasi Kabupaten Sampang berada di sekitar garis khatulistiwa, maka seperti kabupaten lainya di Madura, wilayah ini mempunyai perubahan iklim sebanyak 2 jenis setiap tahun, musim kemarau dan musim penghujan. Salah satu tanaman pangan yang menonjol di Kabupaten Sampang adalah ubi kayu, dengan luas lahan 22.309 ha dengan produksi pertahun sebesar 254. ton. Berawal dari melimpahnya tanaman ubi kayu yang ditanam oleh masyarakat di Kabupaten Sampang sehingga banyak penduduk yang mengolah tanaman tersebut menjadi bahan olahan yang layak untuk dijual sebagai makanan khas atau unggulan masyarakat Kabupaten Sampang khususnya Kecamatan Omben Desa Madulang sekaligus layak menjadi oleh-oleh atau makanan khas. Dimana tema kegiatan strategis pengabdian masyarakat yang mengakomodasi cabang keilmuan di lingkungan Uniersitas Dr. Soetomo yaitu mengangkat tema ketahanan pangan dan industri kreatif sehinga hal ini yang menjadikan tim PKM melaksanakan pengabdian masyarakat di Bumdes Madulang ini.

Desa Madulang pada saat KKN PPM Universitas Soetomo telah dibuatkan Web desa Madulang untuk mengenalkan potensi potensi desa termasuk Bumdes Madulang yaitu kripik singkong Tette dan Web ini tidak berjalan karena terkendala dengan keterbatasan kemampuan sumber daya manusia ( operator web ) oleh karena itu untuk lebih mengenalkan Mitra pada program pengabdian masyarakat ini adalah Badan Usaha Milik Desa ( Bumdes) Madulang di Kecamatan Omben Kabupaten Sampang yang dikelola oleh Kepala Desa Madulang yang telah mengelola produksi Kripik Singkong yang dikenal dengan nama Tette beralih tidak menggunakan Web Desa untuk mengenalkan produk Bumdes Madulang dalam memasarkan produk kripik singkong TETTE. Berbagai aplikasi media sosial saat ini dapat menimbulkan peluang untuk melakukan promosi bagi masyarakat dalam melakukan suatu usaha. Peluang terhadap media sosial tidak berhenti hanya pada usaha produk. Usaha jasa maupun pariwisata juga mulai menggunakan media sosial sebagai salah satu sarana untuk menarik perhatian masyarakat untuk membeli produk yang ditawarkan melalui media sosial. Selain itu selama ini Bumdes Madulang Kripik Singkong TETTE selama ini hanya menggunakan salah satu media sosial yaitu Whattshap ( WA ) saja sebagai sarana promosi dalam menjual produknya tetapi Bumdes Madulang masih belum memanfaatkan berbagai aplikasi yang telah disediakan media sosial baik melalui $\mathrm{Hp}$ Android atau fasilitas wifi yang saat ini sudah marak di daerah / desa saat ini sehingga dapat dikatakan belum maksimalnya penggunaan sarana promosi yang menggunakan Media Sosial seperti Instagram dan Facebook yang lebih luas jangkauan promosinya untuk menjual supaya dapat meningkatkan volume penjualan kripik TETTE. 




\section{Gambar 1. Kripik Singkong Bumdes Madulang TETTE}

Gambar 1 tersebut diatas adalah produk kripik singkong Tette yang telah dikemas dan siap untuk dipasarkan. Industri Bumdes kripik singkong yang belum secara luas mengenalkan produknya kepada seluruh khalayak masyarakat, maka mengenalkan tentang media sosial yang sudah banyak digunakan oleh para pemasar produk untuk mengenalkan dan memberikan pelatihan tentang produk mereka bahkan sampai menjual dengan omzet yang sangat melampuai target penjualan dengan melalui instagram dan facebook.

Kripik TETTE di Bumdes Madulang ini merupakan makanan yang mempunyai rasa berbagai macaam diantaranya coklat, keju, balado dan original. Adapun proses produksi yang dilakukan sebagai berikut :

\section{Gambar 2. Skema Proses Produksi Pembuatan Kripik Singkong TETTE}

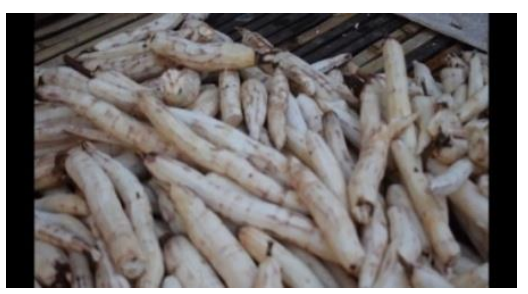

Singkong yang telah dikupas

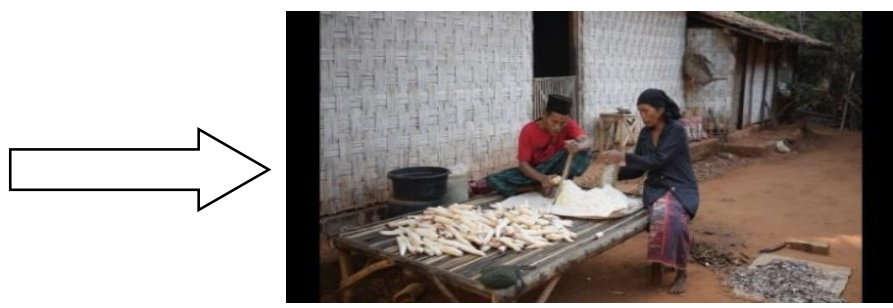

Singkong setelah dicuci kemudian diparut dan diperas atau kripik singkong ditanak setelah matang di tettek dinetuk bulat, setelah itu dijemur<smiles>C1CCCC1</smiles>

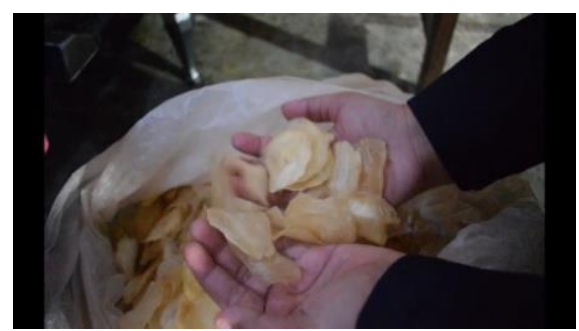

Singkong setelah dijemur dan kering siap digoreng<smiles>C1CCCCC1</smiles> 


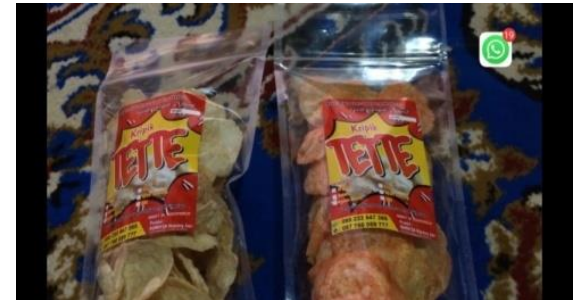

Kripik Singkong TETTE setelah di kemas
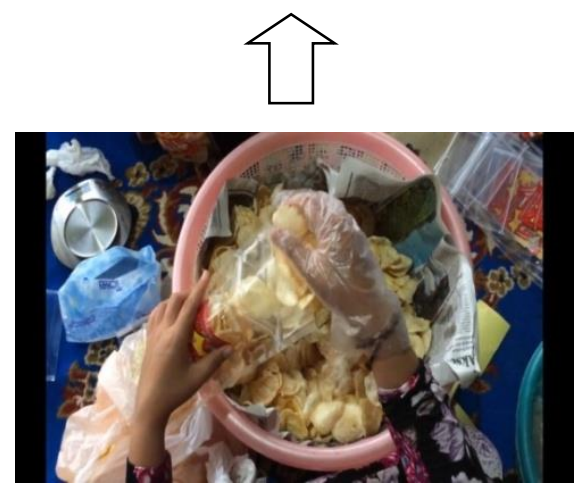

Kripik Singkong siap dikemas

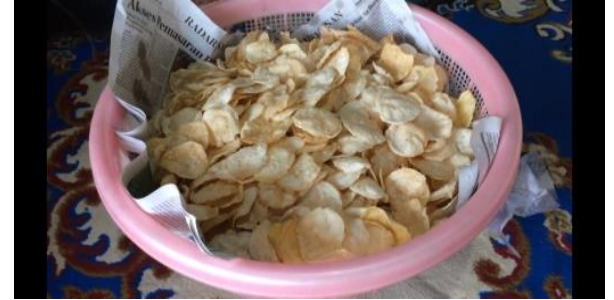

Kripik singkong mentah, setelah digoreng dan ditiriskan
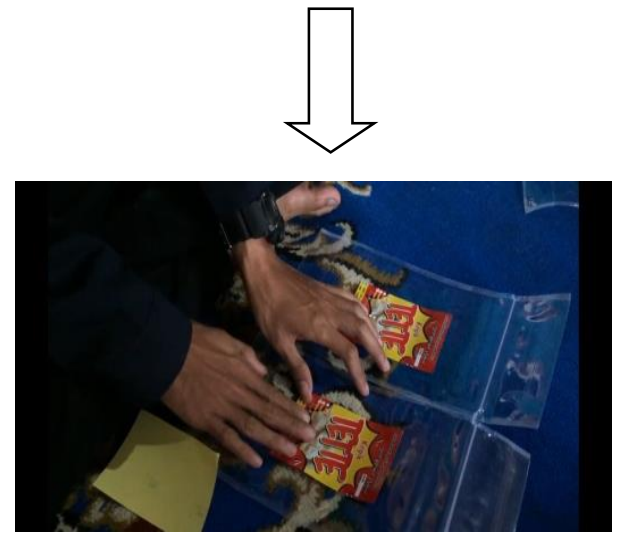

Penyiapan Kemasan

Fasilitas atau sarana dan prasarana yang dimiliki oleh Bumdes Madulang cukup memadai dan sederhana untuk melakukan proses produksi dan dapat memasarkan dengan baik tetapi kurang berinovasi dalam memasarkan produk kripik singkong sehingga perlu dikembangkan lagi melalui sarana promosi menggunakan Instagram dan Facebook, untuk meningkatkan volume penjualan oleh karena itu perlu adanya pendampingan dan pelatihan dalam hal membuat akun Instagram dan Facebook tersebut melalui dana hibah Dipa Universitas Dr. Soetomo sebagai bentuk pengabdian masyarakat.

\section{Permasalahan Mitra}

Berdasarkan analisis situasi, beberapa hal yang dianggap pengusul sebagai masalah prioritas yang harus ditangani dengan mempertimbangkan hal di atas, maka disepakati bahwa yang akan menjadi permasalahan pada program pengabdian adalah masalah cara membuat akun melalui media sosial Instagram dan Facebook serta memasarkan kripik singkong TETTE melalui media sosial Instagram dan Facebook .

Mengacu kepada butir analisis situasi, teridentifikasi masalah utama yang dihadapi mitra, yaitu (1) belum mengenal sarana promosi melalui media sosial (2) belum pernah dilakukannya pembuatan akun Instagram dan Facebook dalam sarana mempromosikan produknya.

\section{METODE PELAKSANAAN}

Berdasarkan uraian sebelumnya, serta hasil diskusi dengan mitra maka prioritas permasalahan yang harus diselesaikan bersama mitra adalah memperbaiki sarana promosi melalui penggunaan media sosial yaitu facebook dan instagram pada produk kripik singkong TETTE :

Tahap 1, Perencanaan. Langkah - langkah tersebut yaitu :

a. Melakukan diskusi lebih mendalam tentang kebutuhan mitra dengan membuka wacana pentingnya promosi melalui akun medsos yaitu facebook dan instagram 
b. Mempersiapkan materi pelatihan bersama dengan tim pengabdian dari survey awal yang dilakukan kepada mitra.

Tahap 2, Pelaksanaan. Pada tahap pelaksanaan ini langkah-langkah yang digunakan yaitu :

a. Tim memberikan materi pengetahuan tentang pemasaran melalui media sosial dengan menggunakan HP Android / Wifi kepada mitra melalui akun facebook dan instagram sebagai sarana promosi pada kripik singkong TETTE .

b. Pendampingan pembuatan akun facebook dan instagram kepada Mitra Bumdes Madulang

c. Membuat foto-foto dan video promosi kripik singkong TETTE secara bersama-sama antara pihak tim PKM , pendamping desa Madulang dan pengelola badan usaha milik desa.

d. Memasukkan semua foto dan video promosi kripik TETTE di Akun Facebook dan Instagram yang diberi nama dengan kripiktettesampang ( Fb ) dan kripiktette.sampang ( lg )

\section{Tahap 3, Evaluasi.}

Pada tahap ini, langkah yang digunakan yaitu mengevaluasi hasil pelatihan dan pendampingan pembuatan akun facebook dan instagram dan tehnik-tehnik lainnya sebagai peningkatan sarana promosi yang mana promosi merupakan salah satu unsur marketing mix, melalui pembenahan sarana promosi yang dalam hal ini belum dilakukan oleh Bumdes Madulang selama ini yaitu penggunaan media sosial facebook dan instagram untuk meningkatkan penjualan produk TETTE. Dimana sejak telah melakukan promosi dengan menggunakan akun facebook dan instagram penjualan kripik

\section{HASIL DAN PEMBAHASAN}

Penetapan prioritas masalah yang akan diselesaikan selama program pengabdian dan solusi masalah yang disepakati untuk diselesaikan dibagi menjadi tiga tahapan :

Tahap 1, Perencanaan. Adapun langkah - langkah tersebut yaitu :

a. Tim pengabdian melakukan diskusi lebih mendalam tentang kebutuhan mitra dengan membuka wacana pentingnya promosi melalui akun medsos yaitu facebook dan instagram untuk mendapatkan konsumen yang lebih banyak untuk lebih kenal dengan produk kripik singkong tette

Gambar 3. Survey Awal ke Bumdes Madulang

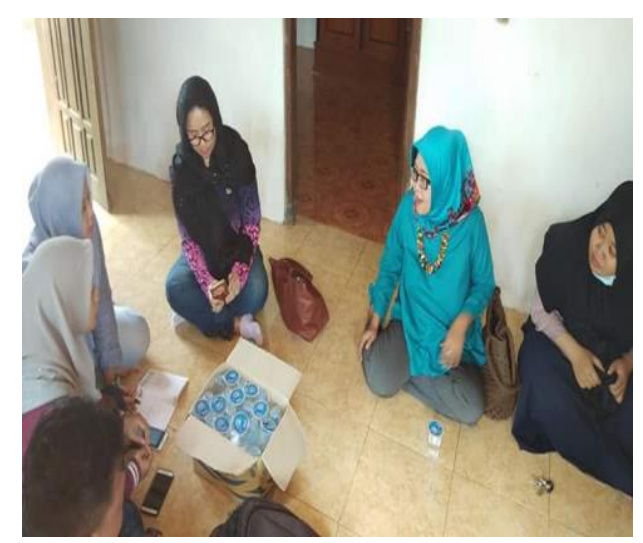

b. Mempersiapkan materi pelatihan bersama dengan tim pengabdian dari survey awal yang dilakukan kepada mitra. 
Tahap 2, Pelaksanaan. Pada tahap pelaksanaan ini langkah-langkah yang digunakan yaitu :

a. Tim memberikan materi pengetahuan tentang pemasaran melalui media sosial dengan menggunakan HP Android / Wifi kepada mitra melalui akun facebook dan instagram sebagai sarana promosi pada kripik singkong TETTE.

Gambar 4. Pemberian Materi Pelatihan kepada Pengelola Bumdes Madulang
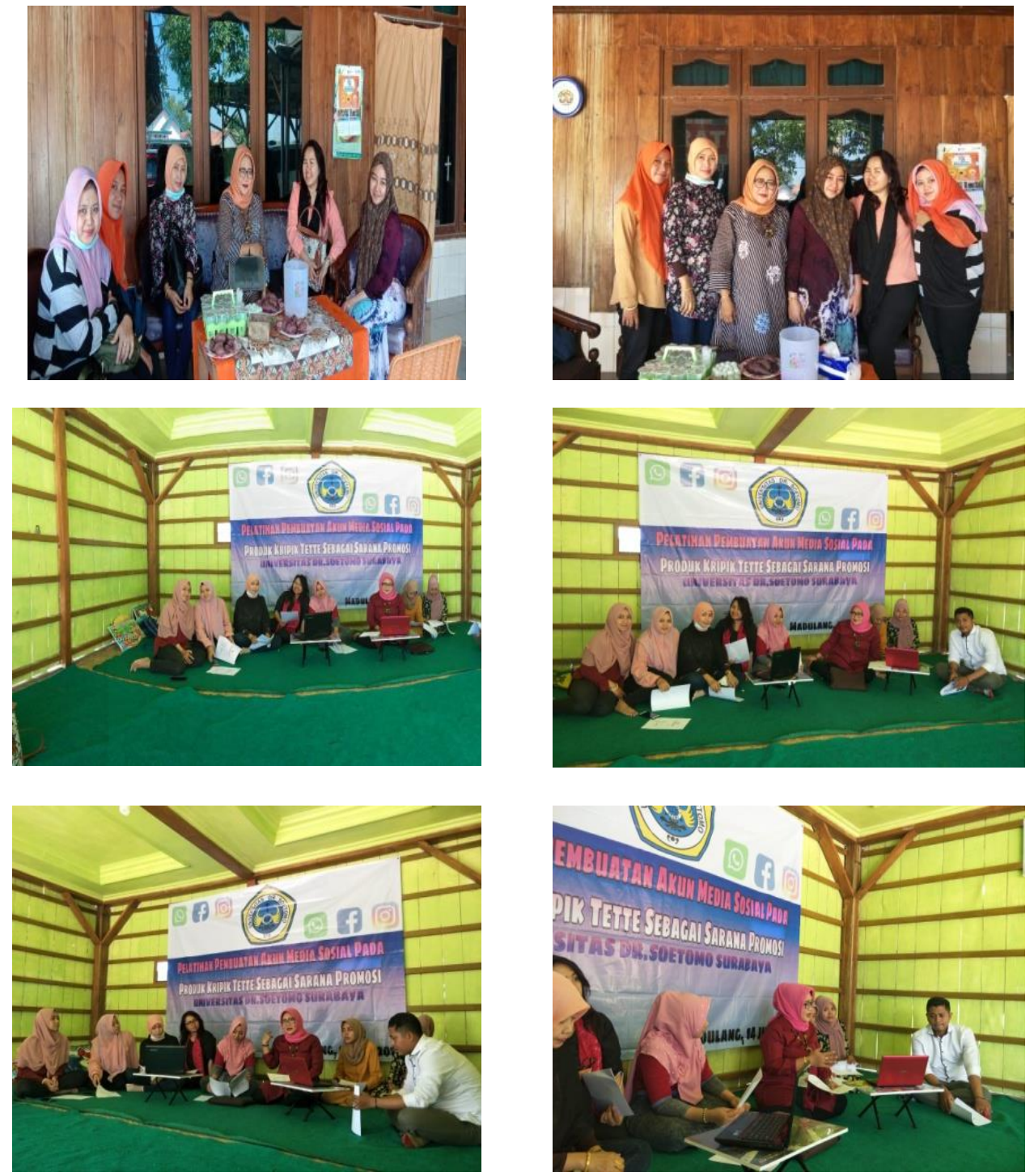

b. Pendampingan pembuatan akun facebook dan instagram kepada Mitra Bumdes Madulang 
Gambar 5. Pendampingan Pembuatan Akun
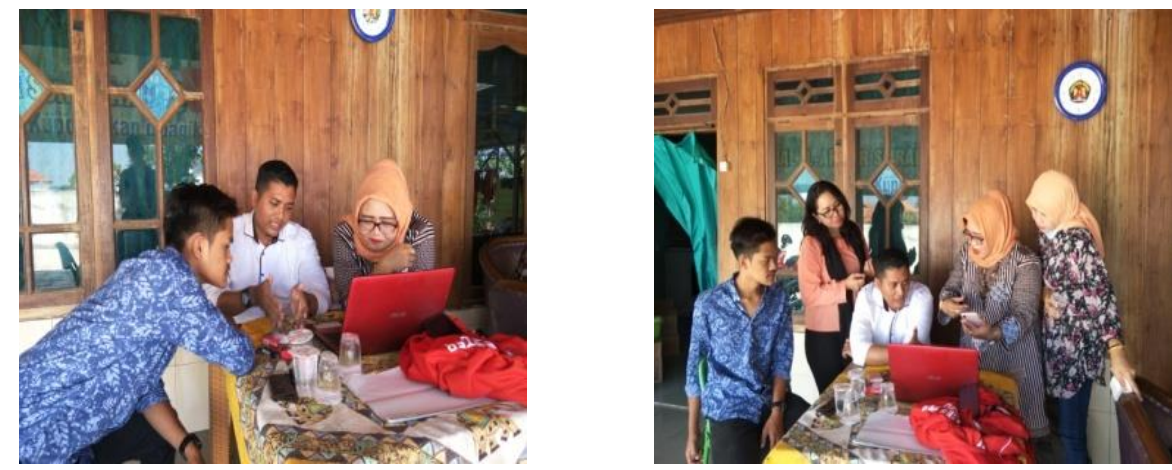



Akun Instagram



Kripiktettesampang



Akun Facebook

c. Membuat foto-foto dan video promosi kripik singkong TETTE secara bersama-sama antara pihak tim PKM, pendamping desa Madulang dan pengelola badan usaha milik desa.

Gambar 6. Foto-Foto dan Video Kripik Singkong Tette di Akun


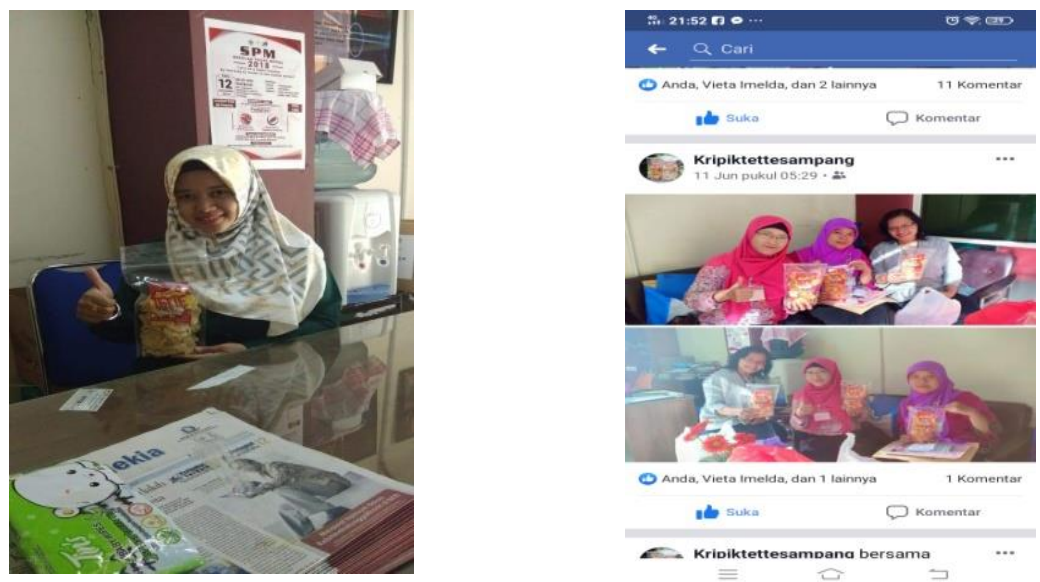

d. Memasukkan semua foto dan video promosi kripik TETTE di Akun Facebook dan Instagram yang diberi nama dengan kripiktettesampang ( Fb ) dan kripiktette.sampang ( lg )

\section{Tahap 3, Evaluasi.}

Pada tahap ini, langkah yang digunakan yaitu mengevaluasi hasil pelatihan dan pendampingan pembuatan akun facebook dan instagram dan tehnik-tehnik lainnya sebagai peningkatan sarana promosi yang mana promosi merupakan salah satu unsur marketing mix, melalui pembenahan sarana promosi yang dalam hal ini belum dilakukan oleh Bumdes Madulang selama ini yaitu penggunaan media sosial facebook dan instagram untuk meningkatkan penjualan produk TETTE. Dimana sejak telah melakukan promosi dengan menggunakan akun facebook dan instagram penjualan kripik.

Gambar 7. Mengevaluasi Akun Promosi dan Pemberian Hp untuk Promosi
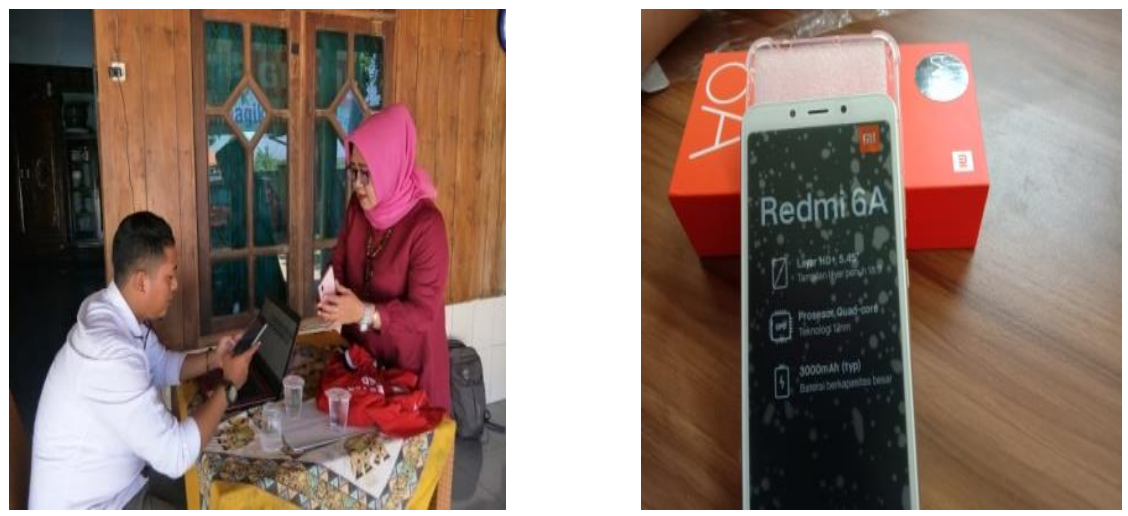


\section{SIMPULAN}

1. Perkembangan media saat ini memberikan berbagai opsi kepada masyarakat untuk menikmati informasi dengan cara yang beragam. Hal ini pula yang mendorong perkembangan sebuah media baru yang dari tahun ke tahun semakin terasa efeknya. Awalnya, kata media sosial bahkan tidak dikenal. Dalam era jejaring sosial sekarang ini terjadi pergeseran dari pemasaran offline ke pemasaran online. Desa Madulang Kecamatan Omben Kabupaten Sampang merupakan salah satu kabupaten yang terletak di Pulau Madura. Di sebelah timur berbatasan dengan Kabupaten Pamekasan. Di sebelah selatan berbatasan dengan Selat Madura. Sedangkan di sebelah barat berbatasan dengan Kabupaten Bangkalan. Luas wilayah Kabupaten Sampang yang mencapai 1233,33 km2 habis dibagi menjadi 14 kecamatan dan 186 desa / Kelurahan. Berawal dari melimpahnya tanaman ubi kayu yang ditanam oleh masyarakat di Kabupaten Sampang sehingga banyak penduduk yang mengolah tanaman tersebut menjadi bahan olahan yang layak untuk dijual sebagai makanan khas atau unggulan masyarakat Kabupaten Sampang khususnya Kecamatan Omben Desa Madulang sekaligus layak sebagai oleh-oleh atau makanan khas. Salah satu tema kegiatan strategis pengabdian masyarakat yang mengakomodasi cabang keilmuan di lingkungan Uniersitas Dr. Soetomo yaitu mengangkat tema ketahanan pangan dan industri kreatif sehinga hal ini yang menjadikan tim PKM melaksanakan pengabdian masyarakat di Bumdes Madulang ini. Beberapa hal yang dianggap sebagai masalah prioritas oleh mitra Bumdes Madulang yang harus ditangani maka disepakati bahwa yang akan menjadi permasalahan pada program pengabdian adalah masalah cara membuat akun melalui media sosial Instagram dan Facebook serta memasarkan kripik singkong TETTE melalui media sosial Instagram dan Facebook.

2. Solusi yang diberikan berupa pelatihan (pembinaan dan pendampingan) yang dilakukan dengan strategi kronologis atau bertahap yang pertama yaitu memberikan pengetahuan / membuka wawasan kepada pengusaha Badan Usaha Milik Desa Madulang tentang begitu pentingnya penggunaan media sosial facebook dan instagram sebagai sarana promosi kripik singkong TETTE dan yang kedua memberikan pelatihan pembuatan akun facebook dan instagram sebagai sarana promosi kripik singkong TETTE. Kegiatan solusi yang ketiga membuat foto-foto dan video promosi kripik sigkong TETTE untuk mengisi Akun Facebook dan Instagram dan yang keempat solusi yang disepakati yaitu melakukan evaluasi dalam melakukan promosi kripik sigkong TETTE yang telah dilakukan oleh Badan Usaha Milik Desa Madulang melalui akun medsos Facebook dan Instagram. 


\section{DAFTAR PUSTAKA}

Artikel non-personal. 5 Maret 2013. Internet. Wikipedia

Bahasa

Indonesia.

http://id.wikipedia.org/wiki//nternet.Diakses 6 Maret 2013

Artikel non-personal. 21 Februari 2013, Pemasaran Internet. Wikipedia Bahasa

Indonesia. http://id.wikipedia.org/wiki/Pemasaran_I nternet. Diakses 6 Maret 2013

Artikel non-personal. 22 Februari 2013. Facebook. Wikipedia Bahasa Indonesia. http://id.wikipedia.org/wiki/Facebook. Diakses 6 Maret 2013

Nur Syam, Media Sosial : Interaksi , Identitas dan Modal, Usaha. Penerbit Shefty Dyah Ayusi, 2017

Usmara. 2003. Strategi Baru Manajemen Pemasaran. Yogyakarta: PT. Amara Books 